\section{Relation of availability and barley uptake of some potentially toxic elements}

\author{
László Fodor \\ Károly Róbert College, Gyöngyös \\ lfodor@karolyrobert.hu
}

\section{SUMMARY}

A small-plot microelement load field trial was set up on brown forest clay soil with eight elements ( $\mathrm{Al}, \mathrm{As}, \mathrm{Cd}, \mathrm{Cr}, \mathrm{Cu}, \mathrm{Hg}, \mathrm{Pb}$, $\mathrm{Zn})$, on 3 levels each $\left(0 / 30,90,270 \mathrm{~kg}\right.$ element $\left.\mathrm{ha}^{-1}\right)$. The soil was treated with soluble salts of elements once at initiation (1994). In the seventh year of the experiment (2001) winter barley was the test plant. The total element content was determined in plant samples (shoot, straw, grain) after microwave digestion using cc. $\mathrm{HNO}_{3}+c \mathrm{c} . \mathrm{H}_{2} \mathrm{O}_{2}$. The element composition of the prepared samples was determined using ICP-MS technique. In the experiment toxic effects of treatments and yield loss could not be observed. $\mathrm{Zn}$ and As contents in barely shoots were only moderately increased by increasing microelement loads. Effects of $\mathrm{Cr}, \mathrm{Cu}, \mathrm{Hg}, \mathrm{Pb}$ and $\mathrm{Al}$ treatments could not be observed. On the other hand, Cd accumulation was significant in the shoot. Cd content was also increased both in straw and grain. Results of this experiment prove that $\mathrm{Cd}$ remains mobile in the soil-plant system for a long time. Its accumulation can be observed both in vegetative and reproductive parts of plants without toxic symptoms and yield loss.

Keywords: toxic elements, soil availability, crops, accumulation

\section{INTRODUCTION}

Environmental pollution is an ever-increasing load on the various resources of our environment, including soils. Tests and experiments involving heavy metals and other potentially toxic microelements play a very important role in our environmental research programs (Kádár, 1995; Simon, 1999). Soils containing high level of microelement concentration can be found in industrial and urban areas, along motorways and areas treated with heavy application of waste-water sludge, but soils can also be "polluted" geologically. Soils are able to accumulate heavy metals for many years without obvious signs of their acute toxic effect. However, the buffering capacity of soils is finite. Above a certain level they are no longer to absorb these elements and they become sources of pollution themselves. Toxic elements are released into water, absorbed by cultivated crops and plants (Lehoczky et al., 2000; Szabó and Fodor, 1998; Fodor and Szabó, 2004). Winter barley (Hordeum vulgare L.) is one of the most important cultivated cereals. Its seeding area varies between 150000 200000 ha in Hungary. On less fertile soils winter barley yields better than winter wheat and it can be harvested earlier, than the other cereals. Most of the winter barley is used for livestock feeding. The barley grain has higher protein content and better amino acid composition than the corn seed. It has also more fibre, therefore barley grain is an easily digested feeding stuff. Some varieties appropriate for malting. Unfortunately we have not enough information related to sensitivity of barley to the soil pollution or to the high microelement concentration in the soil. Kádár (2003) published results of microelement load field experiment with winter barley that was set up on calcareous chernozem soil. This paper gives some data about element composition of winter barley grown on treated slightly acid brown forest soil with high rates of microelements.

\section{MATERIALS AND METHODS}

The long term field experiment on microelement loading was established in 1994 at Tass-puszta Model Farm of the Károly Róbert College. The soil type of the experiment field is a slightly acid chernozem brown-forest soil (vertic cambisol). Its main characteristics are as follows: $\mathrm{pH}_{(\mathrm{H} 2 \mathrm{O})}=6.4$; $\mathrm{pH}_{(\mathrm{KCl})}=5.4 ; \mathrm{y}_{1}=9.5 ; \mathrm{CaCO}_{3} \%=0$; humus content $=3 \%$; upper limit of plasticity $\left(\mathrm{K}_{\mathrm{A}}\right)=45$. The dominant mineral particles are clay and silt. The soil textural class is clayey-loam with a bulk density $1.21 \mathrm{~g} \mathrm{~cm}^{-3}$. The cation exchange capacity (CEC) (T-value) of the soil is $40 \mathrm{meq} 100 \mathrm{~g} \mathrm{soil}{ }^{-1}$. The amount of exchangeable basic cations (S-value) is $36 \mathrm{meq} 100 \mathrm{~g}$ soil $^{-1}$, thus base saturation $(\mathrm{V} \%)$ is $90 \%$. The breakdown of exchangeable cations is the following: $\mathrm{Ca}^{++} 83 \%, \mathrm{Mg}^{++} 10 \%, \mathrm{Na}^{+} 6 \%, \mathrm{~K}^{+} 1 \%$. The hydrologic properties of the soil: well drained, good hydraulic conductivity and adequate pore sizes for water retention.

The experiment is designed as a split-plot, where the 8 tested elements $(\mathrm{Al}, \mathrm{As}, \mathrm{Cd}, \mathrm{Cr}, \mathrm{Cu}, \mathrm{Hg}, \mathrm{Pb}$, $\mathrm{Zn})$ are the main plots, the applied 3 load levels $\left(0 / 30,90\right.$ and $\left.270 \mathrm{~kg} \cdot \mathrm{ha}^{-1}\right)$ are the sub plots. The plot size is $35 \mathrm{~m}^{3}$ each, with 3 replications. Soil treatments were conducted once at initiation (1994) using the water soluble salts of the above elements (Table 1).

Table 1

Treatments of the field trial

\begin{tabular}{|c|c|c|c|c|}
\hline \multirow{2}{*}{ Element } & \multicolumn{3}{|c|}{ Loading levels, kg element ha ${ }^{-1}$} & \multirow{2}{*}{$\begin{array}{c}\text { Form of salt } \\
\text { applied }\end{array}$} \\
\hline & 1 & 2 & 3 & \\
\hline $\mathrm{Al}$ & 0 & 90 & 270 & $\mathrm{Al}\left(\mathrm{NO}_{3}\right)_{3} \cdot 9 \mathrm{H}_{2} \mathrm{O}$ \\
\hline As & 30 & 90 & 270 & $\mathrm{NaAsO}_{2}$ \\
\hline $\mathrm{Cd}$ & 30 & 90 & 270 & $3 \mathrm{CdSO}_{4} \cdot 8 \mathrm{H}_{2} \mathrm{O}$ \\
\hline $\mathrm{Cr}$ & 30 & 90 & 270 & $\mathrm{~K}_{2} \mathrm{CrO}_{4}$ \\
\hline $\mathrm{Cu}$ & 30 & 90 & 270 & $\mathrm{CuSO}_{4} \cdot 5 \mathrm{H}_{2} \mathrm{O}$ \\
\hline $\mathrm{Hg}$ & 30 & 90 & 270 & $\mathrm{HgCl}_{2}$ \\
\hline $\mathrm{Pb}$ & 30 & 90 & 270 & $\mathrm{~Pb}\left(\mathrm{NO}_{3}\right)_{2}$ \\
\hline $\mathrm{Zn}$ & 30 & 90 & 270 & $\mathrm{ZnSO}_{4} \cdot 7 \mathrm{H}_{2} \mathrm{O}$ \\
\hline
\end{tabular}


The experimental plots were cultivated with commonly used agrotechnics each year. In 2001, winter barley was the test plant. Plant samples were taken at the end of the shoot stage $(4 \times 0.5 \mathrm{~m}$ above ground part per plot) and at harvest (straw and grain) After weighting, drying and grinding, the element content of prepared samples was determined after microwave digestion using cc. $\mathrm{HNO}_{3}+\mathrm{cc} \cdot \mathrm{H}_{2} \mathrm{O}_{2}$. The element composition was analysed by inductively coupled plasma spectrometry (ICP-AES) detecting 25 elements. Soil samples were taken from the upper horizon of the soil $(0-20 \mathrm{~cm})$ after harvesting. The soil samples were subjected to the Lakanen-Erviö (1971) test, using $\mathrm{NH}_{4}$-acetate+EDTA extraction solution to determine the amount of soluble elements. Total element concentration was also determined using the extracting solution cc. $\mathrm{HNO}_{3}+\mathrm{cc} \cdot \mathrm{H}_{2} \mathrm{O}_{2}$. ICP AES was used to analyse the element concentration in the soil samples.

\section{RESULTS AND DISCUSSIONS}

After 7 years of the soil treatment microelement applications did not prove to be toxic to winter barley, even the high doses (90 and $270 \mathrm{~kg} \mathrm{ha}^{-1}$ ) of applied elements. Soil treatments did not decrease the growth of plants. The test plants were healthy and well developed. The fresh weight and dry matter content of shoot samples varied not significantly in the treatments $\left(1.4-1.6 \mathrm{~kg} 0.5 \mathrm{~m}^{-2}\right.$ fresh weight and

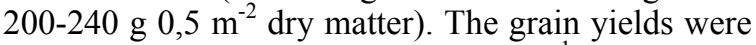
also similar on each plot (5.8-6.4 $\left.\mathrm{t} \mathrm{ha}^{-1}\right)$, significant yield loss was not observable. In the first experimental year (1995) also cereal (winter wheat) was the test plant. At that time $\mathrm{Cr}$ and $\mathrm{Zn}$ treatments were highly as well as $\mathrm{As}$ and $\mathrm{Cu}$ loads were moderately phytotoxic.

$\mathrm{Al}$ content of plant samples was not influenced by the Al load of the soil. Al-silicates are the most abundant soil minerals. Therefore, in proportion to their mass, a 90 or even $270 \mathrm{~kg} \mathrm{ha}^{-1} \mathrm{Al}$ application rate did not cause a detectable change. In 7 years the added $\mathrm{Hg}$ became insoluble in the soil and unavailable for plants. $\mathrm{Hg}$ could not be detected in all of the plant samples with the used analytical method. $\mathrm{Pb}$ content was also under the detectable limit $\left(0.1 \mathrm{mg} \mathrm{kg}^{-1}\right)$ in each sample. In earlier years plant tests also proved, that $\mathrm{Pb}$ is not mobile in the soilplant system. Its concentration remained on the same level in crops (Fodor, 2002).

Concentration of other examined elements in the shoot, straw and grain samples are presented in Table 2. As showed only a moderate enrichment in barley with increasing application. The As content of plants originating from untreated soil was under the detectable limit. The increase of its concentration in examined plant organs was only moderate with increasing As application to the soil. In case of the highest As load $\left(270 \mathrm{~kg} \mathrm{ha}^{-1}\right)$, the detectable As content varied between $0.27-0.39 \mathrm{mg} \mathrm{kg}{ }^{-1}$ in the barley. The highest concentration was measured in the straw. In 1995, winter wheat accumulated about ten times as much As as barley did 7 years later. Results of plant analysis showed, that As mobility decreased considerably in the soil-plant system.

Effect of treatments on the element content of winter barley

(Tass-puszta, 2001)

\begin{tabular}{|c|c|c|c|c|c|c|}
\hline \multirow[t]{2}{*}{ Plant sample } & \multirow{2}{*}{$\begin{array}{c}\text { On the control } \\
\text { soil }\end{array}$} & \multicolumn{3}{|c|}{$\begin{array}{c}\text { Treatment in autumn } 1994 \\
\text { kg element ha }\end{array}$} & \multirow[t]{2}{*}{$\mathbf{L S D}_{5 \%}$} & \multirow[t]{2}{*}{ Average } \\
\hline & & 30 & 90 & 270 & & \\
\hline \multicolumn{7}{|c|}{ Effect of As load, $\mathrm{mg} \mathrm{kg}^{-1}$} \\
\hline Shoot & 0 & 0.12 & 0.21 & 0.27 & 0.17 & 0.2 \\
\hline Straw & 0 & 0.10 & 0.10 & 0.39 & 0.26 & 0.16 \\
\hline Grain & 0 & 0.10 & 0.35 & 0.31 & 0.46 & 0.24 \\
\hline \multicolumn{7}{|c|}{ Effect of Cd load, $\mathrm{mg} \mathrm{kg}^{-1}$} \\
\hline Shoot & 0 & 0.09 & 0.10 & 1.18 & 0.21 & 0.43 \\
\hline Straw & 0.07 & 0.50 & 1.00 & 1.73 & 0.23 & 1.07 \\
\hline Grain & 0.04 & 0.17 & 0.33 & 0.50 & 0.05 & 0.33 \\
\hline \multicolumn{7}{|c|}{ Effect of Cr load, $\mathrm{mg} \mathrm{kg}^{-1}$} \\
\hline Shoot & 0.70 & 0.80 & 0.71 & 0.81 & 0.62 & 0.77 \\
\hline Straw & 2.5 & 2.4 & 2.5 & 3.7 & 3.8 & 2.8 \\
\hline Grain & 0.29 & 0.28 & 0.37 & 0.75 & 0.63 & 0.46 \\
\hline \multicolumn{7}{|c|}{ Effect of Cu load, $\mathrm{mg} \mathrm{kg}^{-1}$} \\
\hline Shoot & 3.5 & 3.9 & 3.9 & 4.3 & 0.6 & 4.0 \\
\hline Straw & 2.6 & 2.6 & 2.7 & 2.7 & 0.9 & 2.7 \\
\hline Grain & 3.6 & 4.0 & 3.9 & 4.0 & 0.5 & 4.0 \\
\hline \multicolumn{7}{|c|}{ Effect of Zn load, $\mathrm{mg} \mathrm{kg}^{-1}$} \\
\hline Shoot & 16.4 & 19.0 & 20.9 & 24.8 & 5.8 & 21.6 \\
\hline Straw & 12.3 & 14.9 & 13.4 & 19.1 & 4.6 & 15.8 \\
\hline Grain & 30.6 & 33.1 & 39.0 & 37.3 & 7.3 & 36.4 \\
\hline
\end{tabular}


In environmental respect, $\mathrm{Cd}$ is the most dangerous microelement in this field experiment. $\mathrm{Cd}$ content of control plants was negligible, but its concentration increased significantly in each examined plant organ by increasing $\mathrm{Cd}$ loads to the soil. At the shoot stage concentration of $\mathrm{Cd}$ in the test plant was ten times higher at the biggest load than in the other two treatments. The highest $\mathrm{Cd}$ content was measured at harvest in the straw at each load level. The increase of $\mathrm{Cd}$ concentration was directly proportional to the $\mathrm{Cd}$ application to the soil. The same tendency was also detectable in the grain. Most of the winter barley grains is used for animal feeding. The Hungarian Standard [4/1990. (II. 28.) MÉM] allows $0.5 \mathrm{mg} \mathrm{kg}^{-1} \mathrm{Cd}$ in the feeding stuff. In this experiment each $\mathrm{Cd}$ application to the soil - which was carried out 7 years ago - resulted in less $\mathrm{Cd}$ content in the grain than the standard limit.

$\mathrm{Cr}$ content remained almost unchanged in the barley shoot in the treatments with an average content of $0.7-0.8 \mathrm{mg} \mathrm{kg}^{-1}$. Cr accumulation was not detectable in the straw either. The grain showed the tendency of $\mathrm{Cr}$ increase but the effect of treatments was not significant.

$\mathrm{Cu}$ is an essential microelement for the crop plants. The element composition of barley shoot did not reflect the enhanced $\mathrm{Cu}$ application to the soil. $\mathrm{Cu}$ content remained on the same level in the straw (2.6-2.7 $\left.\mathrm{mg} \mathrm{kg}^{-1}\right)$ and did not change in the harvested grain either (3.9-4.0 $\left.\mathrm{mg} \mathrm{kg}^{-1}\right)$.

$\mathrm{Zn}$ content in winter barley shoot and straw was not affected much by $\mathrm{Zn}$ treatments.
$\mathrm{Zn}$ accumulation was enhanced about by $50 \%$ over the control by rising loads (from $16.4 \mathrm{mg} \mathrm{kg}^{-1}$ to 24.8 $\mathrm{mg} \mathrm{kg}{ }^{-1}$ in the shoot and from $12.3 \mathrm{mg} \mathrm{kg}^{-1}$ to 19.1 $\mathrm{mg} \mathrm{kg}^{-1}$ in the straw). Significant $\mathrm{Zn}$ enrichment was not measurable in the grain; its concentration remained almost on the same level (30-37 $\left.\mathrm{mg} \mathrm{kg}^{-1}\right)$.

The results of the soil analysis are presented in Table 3. Both the "total" amount (extracted using the mixture of concentrated nitric acid and hydrogen peroxide with microwave digestion) and the so called "mobile"/available fraction (extracted with mixture of ammonium-acetate and EDTA) of examined elements were measured in the soil samples. In physiological respects the available element content is more important than the "total" amount. This varied widely for different elements. The $\mathrm{NH}_{4}$-acetate+EDTA extractable fraction of $\mathrm{Hg}$ was below the $0,1 \mathrm{mg} \mathrm{kg}^{-1}$ detection limit. Its bonding in the soil was the most pronounced. The rate of available fraction as compared to the "total" amount was less than $1 \%$ in case of $\mathrm{Cr}, 10-20 \%$ in case of As and $\mathrm{Zn}$ and about $40-60 \%$ for $\mathrm{Cu}$ and $\mathrm{Pb}$. The soil test also provided evidence of the increased mobility/availability of $\mathrm{Cd}$. The $\mathrm{NH}_{4}$-acetate+EDTA extracted $\mathrm{Cd}$ forms represented about $80 \%$ of the "total" amount. For the other $\mathrm{NH}_{4}$-acetate+EDTA well extracted elements $(\mathrm{Pb}, \mathrm{Cu})$, the plant analysis did not prove their mobility in the soil-plant system. $\mathrm{Pb}$ concentration was below the detectable limit and $\mathrm{Cu}$ content remained on the same level in the plant samples.

Effect of treatments on the "total" and available element content in the 0-20 cm layer of the soil (Tass-puszta, 2001)

\begin{tabular}{|c|c|c|c|c|c|c|}
\hline \multirow[t]{2}{*}{ Element } & \multirow{2}{*}{$\begin{array}{c}\text { In the control } \\
\text { soil }\end{array}$} & \multicolumn{3}{|c|}{$\begin{array}{c}\text { Treatments in autumn } 1994 \\
\text { kg element ha }\end{array}$} & \multirow[t]{2}{*}{$\mathbf{L S D}_{5 \%}$} & \multirow[t]{2}{*}{ Average } \\
\hline & & 30 & 90 & 270 & & \\
\hline \multicolumn{7}{|c|}{ (cc. $\mathrm{HNO}_{3}+\mathrm{cc} . \mathrm{H}_{2} \mathrm{O}_{2}$ digestion) } \\
\hline As & 4.1 & 10.0 & 15.4 & 33.4 & 3.5 & 19.6 \\
\hline $\mathrm{Cd}$ & 1.2 & 6.2 & 16.5 & 41.9 & 8.5 & 21.5 \\
\hline $\mathrm{Cr}$ & 57.8 & 57.7 & 70.4 & 89.3 & 5.9 & 72.5 \\
\hline $\mathrm{Cu}$ & 26.3 & 35.6 & 39.9 & 55.4 & 6.7 & 43.7 \\
\hline $\mathrm{Hg}$ & 0 & 0 & 4.5 & 10.4 & 1.7 & 6.0 \\
\hline $\mathrm{Pb}$ & 21.5 & 27.0 & 31.9 & 41.8 & 3.7 & 33.6 \\
\hline $\mathrm{Zn}$ & 88.6 & 103.7 & 100.7 & 112.0 & 14.7 & 105.5 \\
\hline \multicolumn{7}{|c|}{$\begin{array}{l}\text { Available element content } \mathrm{mg} \mathrm{kg}^{-1} \\
\left(\mathrm{NH}_{4} \text {-acetate }+ \text { EDTA extraction) }\right.\end{array}$} \\
\hline As & 0.1 & 1.2 & 2.3 & 7.2 & 0.4 & 3.5 \\
\hline $\mathrm{Cd}$ & 0.5 & 4.7 & 13.3 & 35.2 & 7.4 & 17.7 \\
\hline $\mathrm{Cr}$ & 0 & 0.15 & 0.45 & 0.76 & 0.06 & 0.45 \\
\hline $\mathrm{Cu}$ & 6.9 & 16.6 & 12.4 & 24.7 & 4.2 & 17.9 \\
\hline $\mathrm{Hg}$ & 0 & 0 & 0 & 0 & 0 & 0 \\
\hline $\mathrm{Pb}$ & 8.6 & 11.7 & 16.7 & 25.1 & 3.3 & 17.8 \\
\hline $\mathrm{Zn}$ & 8.7 & 10.7 & 10.5 & 15.8 & 6.7 & 12.3 \\
\hline
\end{tabular}

\section{REFERENCES}

Fodor, L. (2002): Nehézfémek akkumulációja a talaj-növény rendszerben. Veszprémi Egyetem, Georgikon Mezőgazdaságtudományi Kar, Keszthely (PhD thesis in Hungarian).
Fodor, L.-Szabó, L. (2004): Study of heavy metal leaching in the soil. $13^{\text {th }}$ ISCO Conf. Conserving soil and water for society: sharing solutions. Conf. Proc. CD. Brisbane, Australia: 4. 
Kádár, I. (1995): Contamination of the soil-plant-human food chain by chemical elements in Hungary. Research Institute for Soil Science and Agricultural Chemistry of Hungarian Academy of Sciences, Budapest.

Kádár, I. (2003): Mikroelem terhelés hatása az őszi árpára karbonátos csernozjom talajon. Agrokémia és talajtan. 52:105120.

Lakanen, E.-Erviö, R. (1971): A comparison of eight extractions for the determination of plant available micronutrients in soil. Acta Agr. Fenn. 123:223-232.
Lehoczky, É.-Marth, P.-Szabados, I.-Palkovics, M.-Lukács, P. (2000): Influence of soil factors on the accumulation of cadmium by lettuce. Commun. Soil Sci. Plant Anal. 31 (1114): 2425-2431.

Simon, L. (ed.) (1999): Talajszennyeződés, talajtisztítás. Környezetgazdálkodási Intézet, Környezet- és Természetvédelmi Szakkönyvtár és Információs Központ, Budapest.

Szabó, L.-Fodor, L. (1998): Investigation of mobility and availability of some heavy metals in field conditions. In: Soil pollution; Filep, Gy. ed. Agr. Univ. Debrecen, 132-137. 